\title{
Analysis of the Trend of Peri-Urban Development in Minna, Niger State
}

\author{
Olusegun Owoeye Idowu' , Abdullateef Iyanda Bako², Olalekan Tolulope Bodurin Aduloju² \\ ${ }^{1}$ Department of Urban and Regional Planning, Federal University of Technology, Minna, Nigeria \\ ${ }^{2}$ Department of Urban and Regional Planning, University of Ilorin, Ilorin, Nigeria \\ Email: olu.idowu@futminna.edu.ng
}

How to cite this paper: Idowu, O.O., Bako, A.I. and Aduloju, O.T.B. (2020) Analysis of the Trend of Peri-Urban Development in Minna, Niger State. Journal of Geographic Information System, 12, 411-431.

https://doi.org/10.4236/jgis.2020.125025

Received: August 3, 2020

Accepted: September 7, 2020

Published: September 10, 2020

Copyright $\odot 2020$ by author(s) and Scientific Research Publishing Inc. This work is licensed under the Creative Commons Attribution International License (CC BY 4.0).

http://creativecommons.org/licenses/by/4.0/

\begin{abstract}
Current situation of development in Minna has raised many spatial challenges especially in the peri-urban areas. This study analyzed the spatial development of Minna between 1972 and 2015, with a view to determining the trend at which the peri-urban area changes over time. Minna topographical map of 1972, township map of 1979 and the satellite imageries covering 1986, 1996, 2006 and 2015 were employed in this study. Map processing and image classification techniques were used in extracting the information needed. The study revealed that there was over $2000 \%$ increase in the built-up area of Minna within the period understudied. This implies that the peri-urban areas of Minna by 2015 had grown about thirty-two times its size in 1972; thirteen its size in 1979; thrice its size in 1986 and 1996, respectively; and twice of its size in 2006, but, with an increased rate of uncoordinated and unplanned development. It concluded that the planning and development of Minna peri-urban areas should not be left to chance or the interplay of economic variables, but should be guided by strategies that will ensure orderly growth and development. It therefore recommended that the government through the statutory agencies should initiate a strategic development plan proposal known as Peri-urban Area Strategic Development Plans (PuASDP), which is to guide and control every spatial development activities in the peri-urban areas.
\end{abstract}

\section{Keywords}

Development, Image, Map, Peri-Urban, Spatial

\section{Introduction}

[1] reported that as the world moves into the realm of urban age, the dynamism 
and intense vitality of cities become prominent. [2] firmly asserted that cities are products of many forces and are engines of economic development, centres of cultural innovation, social transformation and political change, in such that, any fresh settlement within urban areas is not just the dominant form of habitation for humankind, but also the engine-room of human development. The dominant urban form and spatial planning challenge facing cities in the $21^{\text {st }}$ century is found in the peri-urban areas [3] [4].

Development of the peri-urban areas across the world is one of the most attractive features of the contemporary research in urban studies. The pattern of migration has increased the levels of urbanization, urban agglomeration and peri-urban development [5]. This implies that there is a strong correlation between demographic transformation and urban agglomeration pattern. Thus, the existing urban hierarchies owed their spatial pattern and structure to the transportation system. Indeed, several studies held to this belief, presenting transportation as the key factor responsible for the growth of urban centres in the $18^{\text {th }}$ and $19^{\text {th }}$ centuries [3] [6]. [7] further identified economy, industrialization, government impact and tremendous immigration as few of the underlying factors contributing to peri-urban spatial transformation.

Peri-urban development, though a global challenge, its characteristics and impact vary locally. In Nigeria, the concepts of physical development in peri-urban areas entail construction of buildings and modification to land in order to create more liveable and comfortable environment [8]. Several factors have been adduced for the rapid expansion of the peri-urban areas in Nigeria. These factors, which range from physical, economic, social and political have influenced urban growth [8] [9] [10]. The dynamic and integrative nature of peri-urban areas has been a major constraint, exhibiting sprawled pattern development [9]. The pattern of development in the peri-urban area has been characterized by a wide variety of the undesirable aspects of changes in the fringe areas of cities, often consciously referred to as unplanned and uncontrolled development resulting in poor and much unplanned suburbanization [11] [12].

As noted by [10], massively-scaled peri-urban development in Nigeria had continued under a variety of guises to meet the demand for space for urban accommodation, business and services from a diverse population. To a certain extent, the large scale infrastructural developments in the peri-urban areas have led to ribbon satellite development that takes advantage of massive investment in national assets. These developments suffer from deficiencies in provision of infrastructure and services. The disadvantages of such development reflect in the absence of proper planning and inadequate or/and inappropriate land governance system.

Minna and virtually all other urban areas in Niger State are experiencing growth that is unplanned and uncontrolled growth. The most visible evidence of this development is that of large and rapid development of slums and squatter settlements in both the core and fringe of the major towns in the state. [13] 
noted that Minna has grown beyond its traditional boundary stated in the Minna Master Plan of 1979-2000, creating an informal growth in the areas which are ecologically and physically unstable. Babangida Aliyu, the former Governor of Niger State (2007-2015) rightly observed the cumulative effects of developmental problems and the challenges affecting the peri-urban areas of Minna, which has not only caused damage to the health of the people, but also on the ability of the city to support economic growth [14].

The Master Plan for Minna (1979-2000) expired more than fifteen years. Efforts made in reviewing it ended in the preparation of Vision 3:20:20 document [15]. The document contains three chapters relating to physical planning and development. These are 1) environment and sustainable development; 2) urban and regional development; and 3) housing. Although the document truly outlined the challenges facing both urban and peri-urban areas particularly Minna, but seems to lack the framework and political drive to actualize the objectives contained there-in. It is in the light of the foregoing that, this study was conceived: as a systematic investigation into the trend of development in the peri-urban areas of Minna between 1972 and 2015.

\section{Study Area}

Minna lies between Latitudes $9^{\circ} 33^{\prime}$ and $9^{\circ} 40^{\prime}$ North of the Equator and Longitudes $6^{\circ} 29^{\prime}$ and $6^{\circ} 35^{\prime}$ East of the Greenwich Meridian (Figure 1). The town spanned along the main spine road that separates the city into West and East. This road is from Chanchaga in the South to Maikunkele in the North, covering a distance of about $20 \mathrm{~km}$. The West-East pattern, spanned from Gidan-Kwano along Bida axis in the West, to Maitumbi to Gwada axis, in the East, over a distance of $15 \mathrm{~km}$ (Figure 2).

\section{Neighbourhoods in Minna}

With the introduction of the tradition head (Emir) of Minna in 1957, the town was subdivided into six (6) administrative wards, made up of the old settlement camps and the newly developed neighbourhoods. Later, numbers of wards increased to nine (9) in 1990 to accommodate the growing neighbourhoods at the periphery, but has since increased to twenty-six (Table 1). These neighbourhoods can be classified into core (Figure 3) and peri-urban neighbourhoods (Figure 4).

Table 1. The Minna neighbourhoods.

\begin{tabular}{ll}
\hline List of Neighbourhoods in Minna & \\
\hline Core Neighbourhoods & Peri-Urban Neighbourhoods \\
\hline Minna Central, Angwan Daji, F-Layout, & Barkin-Sale, Bosso Town, Bosso Estate, Chanchaga, \\
GRA, Limawa, Makera, Nassarwa, Sabon & Dutsen-Kura Gwari, Fadikpe, Jikpan, Kpakungun, \\
Gari, Tundunwada South, Tundunwada & Maitumbi, Sauke-Kahuta, Shango, Tayi Village, \\
North, Tunga. & Tudun-Fulani, Nyikangbe/Gbaganu. \\
\hline
\end{tabular}




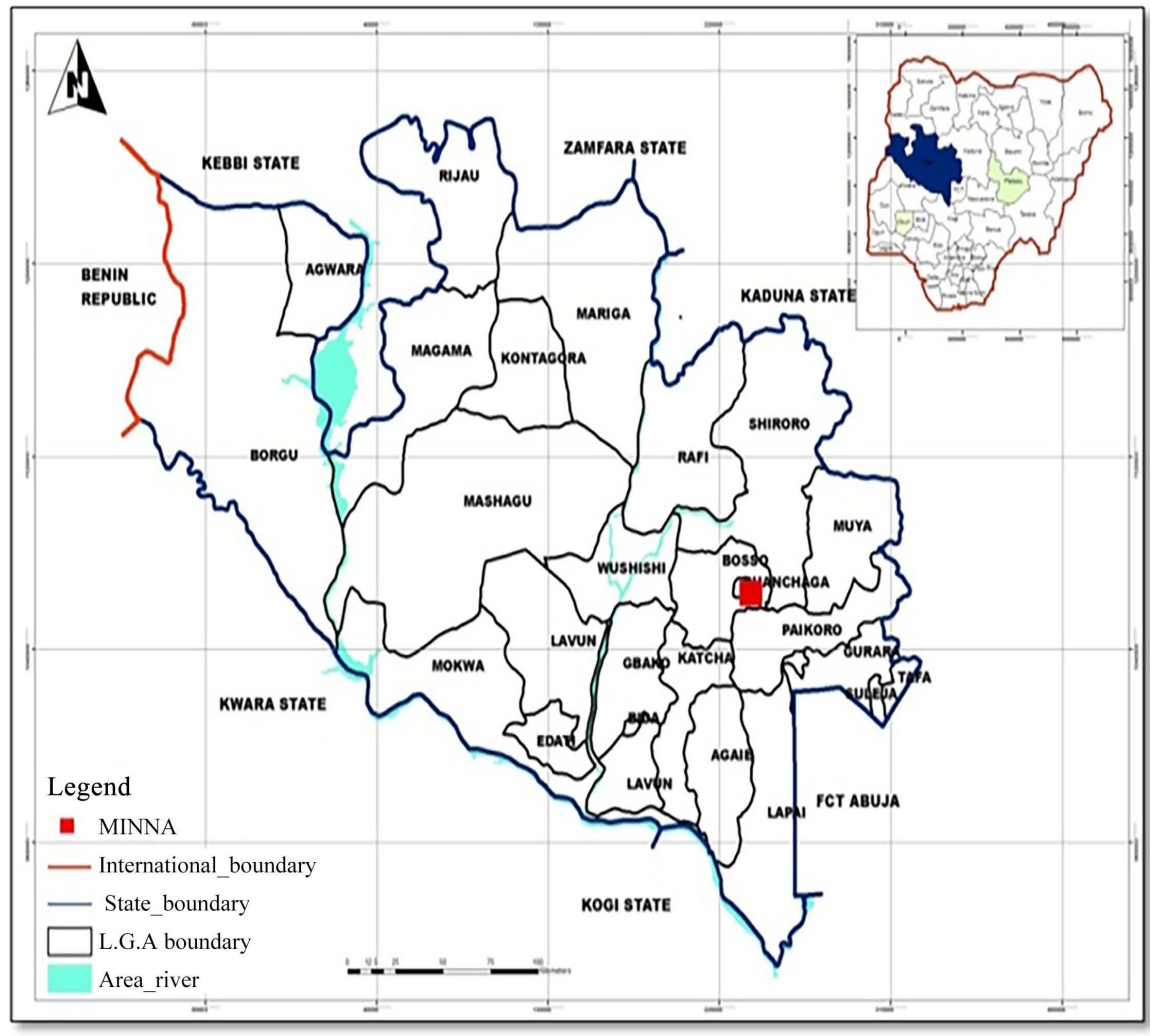

Figure 1. Map of Niger State insert is the map of Nigeria.

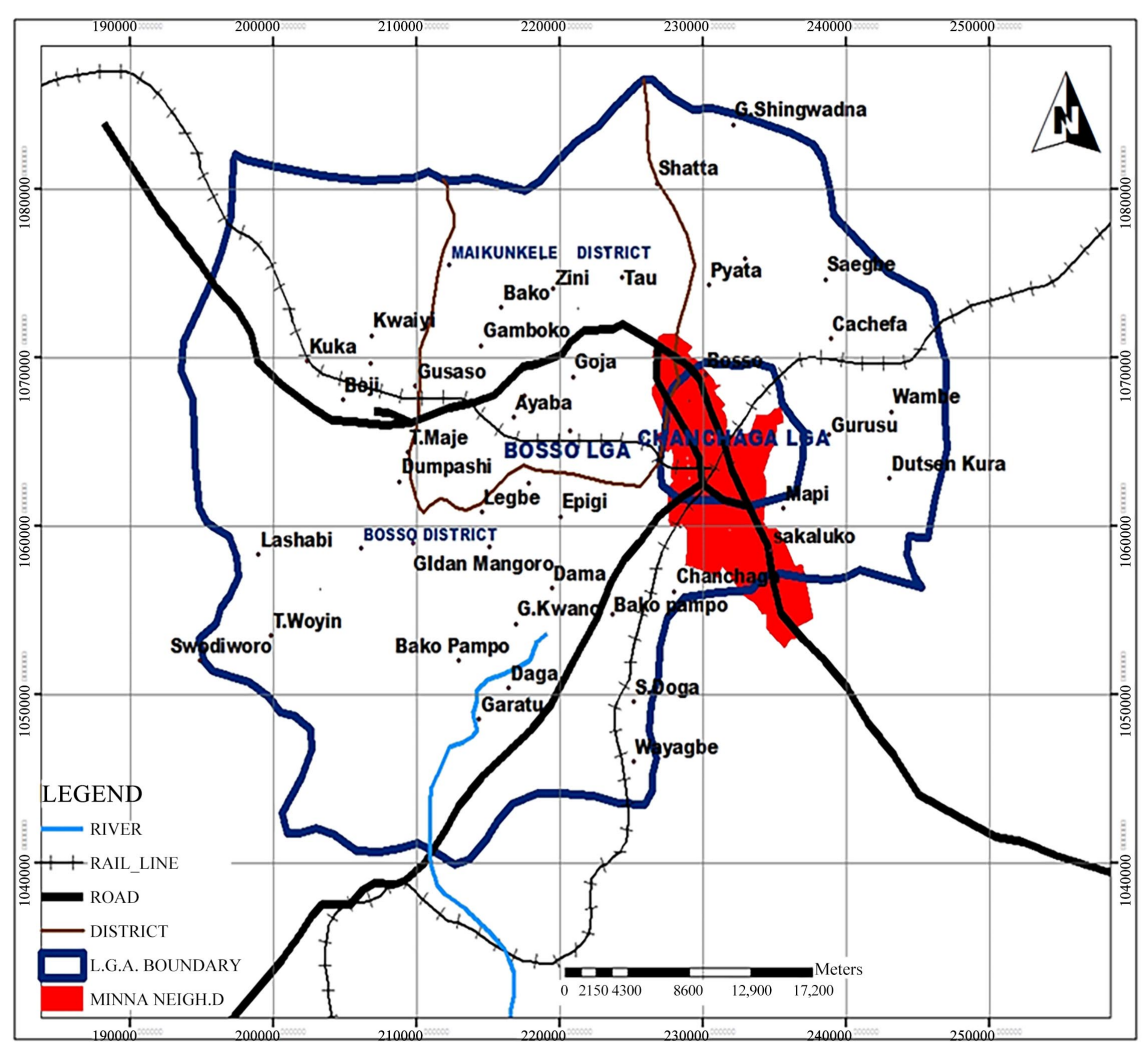

Figure 2. Minna in context of the local government areas. 


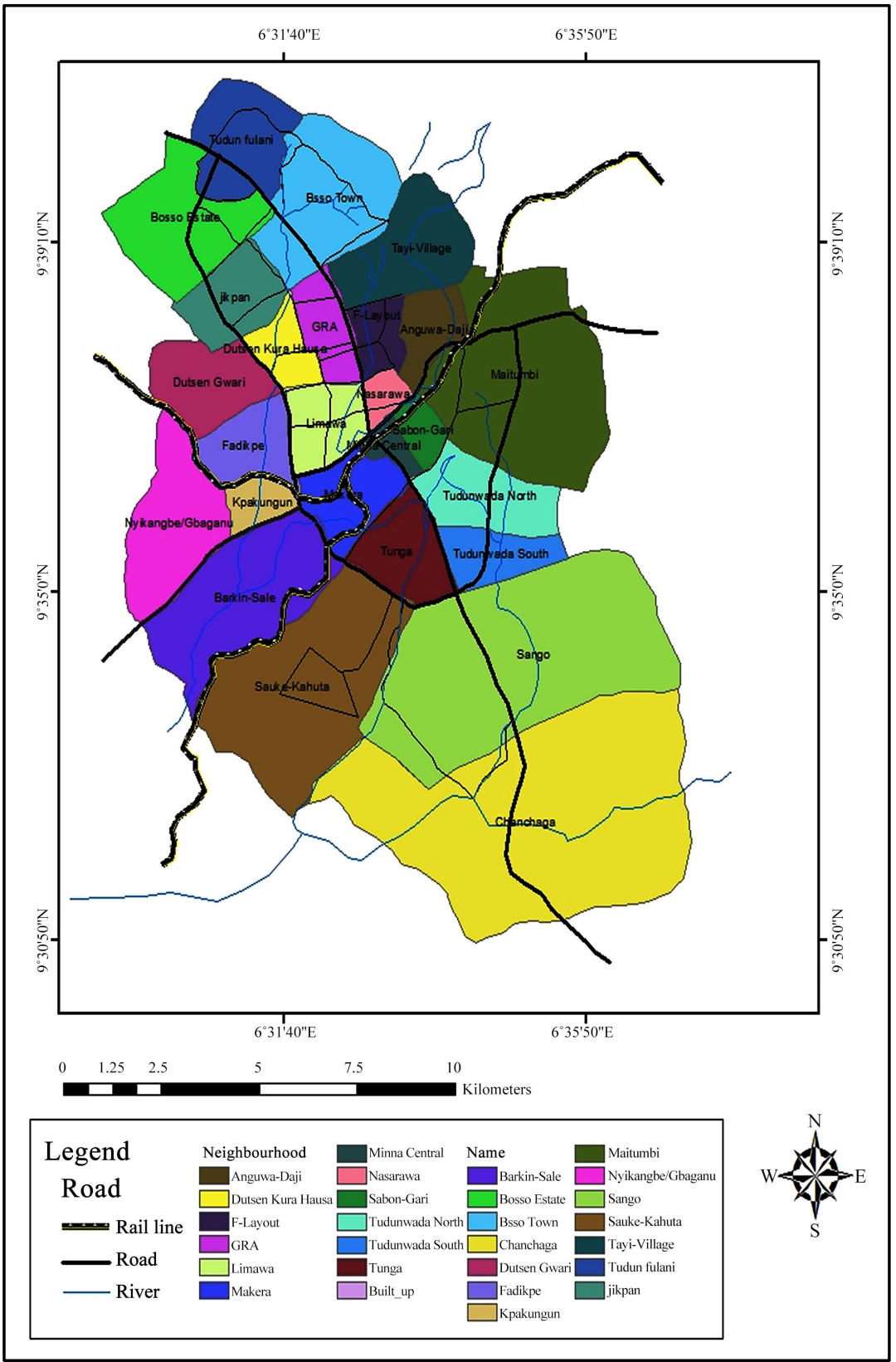

Figure 3. The neighbourhoods/wards in Minna.

\section{Methodology}

A thorough observation of the Minna Master Plan 1979-2000 made the delineation of the peri-urban areas of Minna possible. However, the peri-urban areas (Table 1) studied were not covered by this 1979 Master Plan. The topographical map of 1972; the township map of 1979 (extract from 1979 Master Plan); and the satellite imageries of Minna covering 1986, 1996, 2006 and 2015 were used for peri-urban growth analysis. Remote Sensing and GIS techniques were employed: for map processing, the 1972 topographical map (Figure 5) and the 1979 township map (Figure 6) were geo-referenced and the features digitized using ArcGIS 10.3 software. For the satellite imageries, image processing and classification 
techniques were used in extracting the information needed. To extract the information, three different bands of these imageries were stacked together to develop the false colour composite image (Figures 7-10), thereafter, the area required for the study was subset using ERDAS IMAGINE 9.2 software. For image classification training set, four classes of features were adopted, which are built-up area; undisturbed vegetation; disturbed vegetation; and water body, meanwhile, this study only focuses on the built-up area. These training sets were subjected to the conventional supervised Maximum Likelihood Classification Algorithm using ERDAS IMAGINE 9.2 software. To change the interface of the satellite imageries, this was composed using ERDAS IMAGINE 9.2 software and later transposed to ArcGIS 10.3 software to compose the graticules, legend, scale bar and the true north. Finally, the built-up areas were composed and analyzed using the percentage of the areal extent covered.

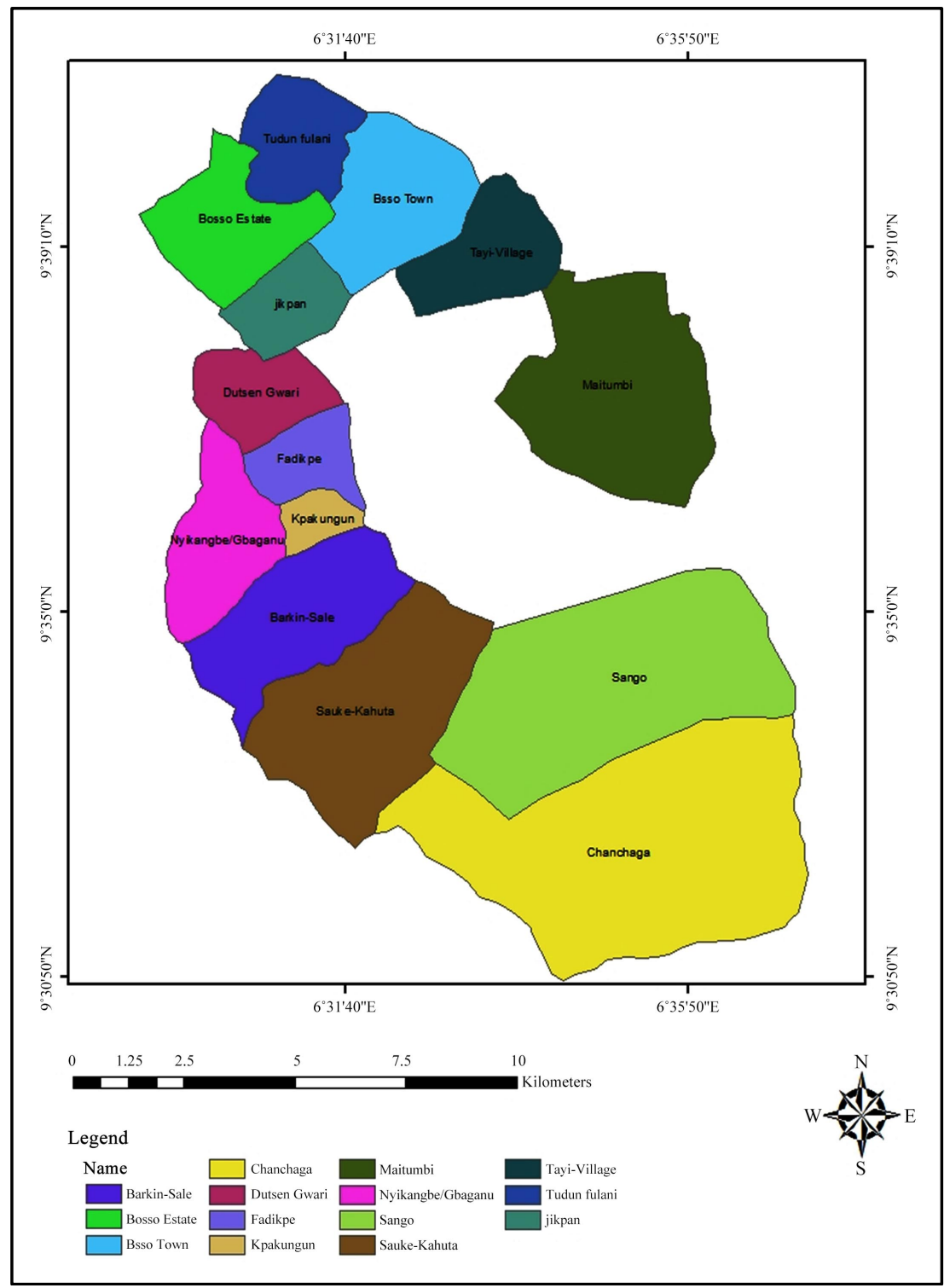

Figure 4. The peri-urban neighbourhoods of Minna. 


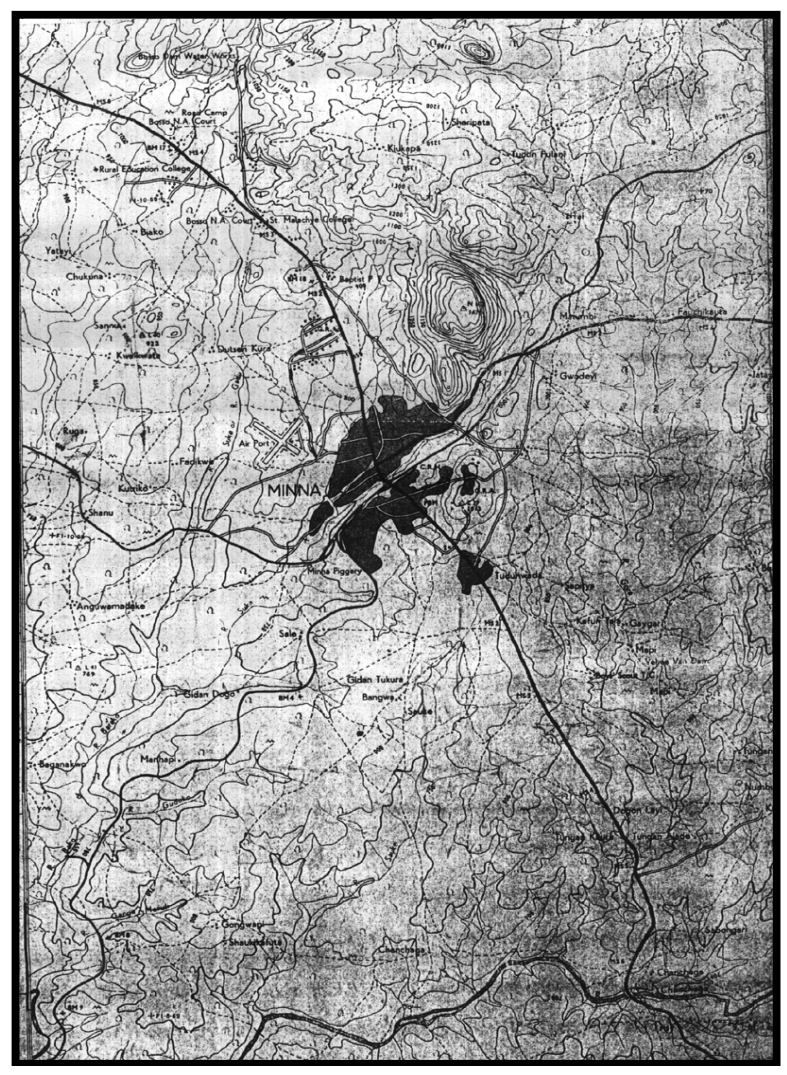

Figure 5. Topographical map of Minna in 1972.

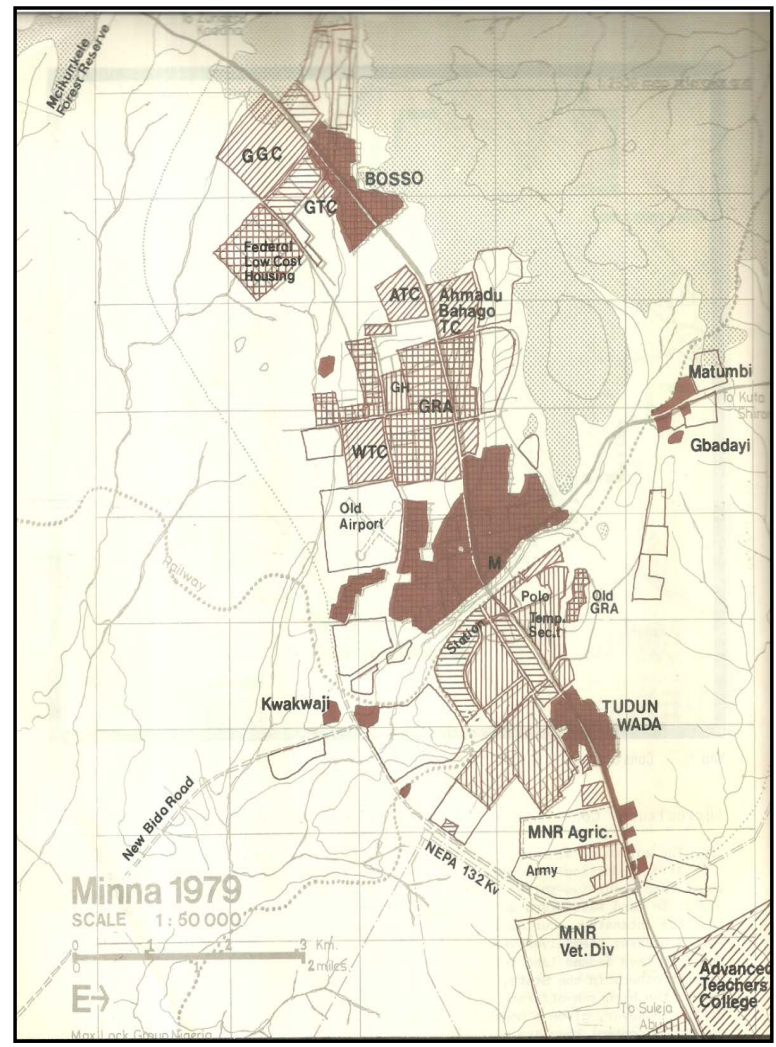

Figure 6. Township map (Master Plan) 1979. 


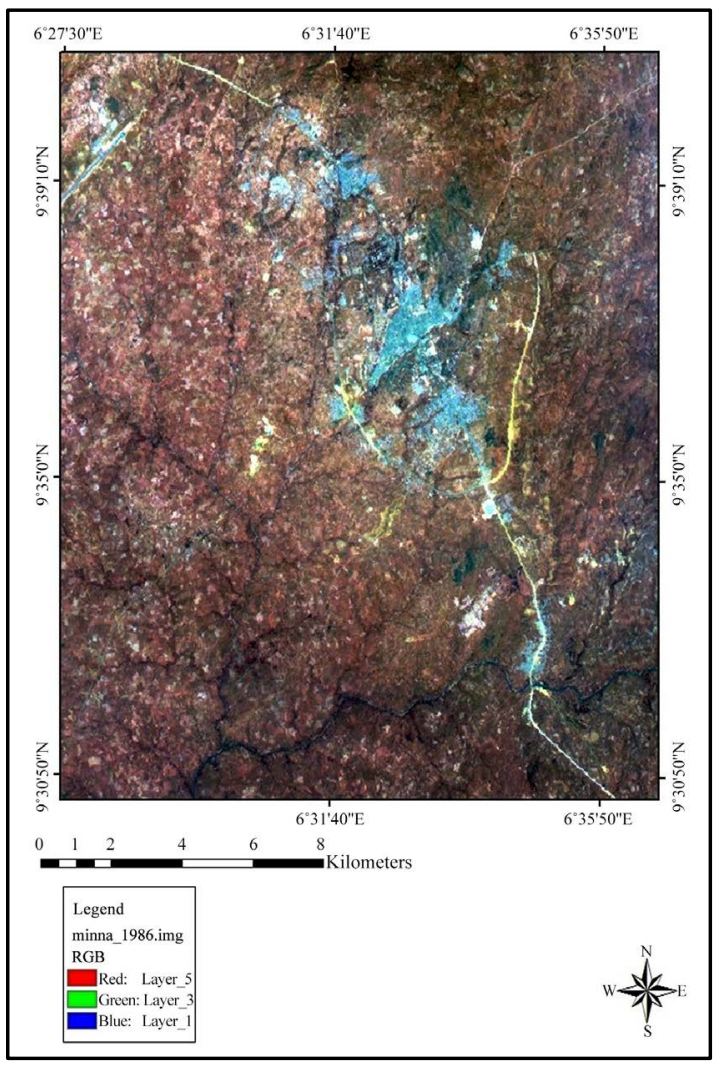

Figure 7. False colour composite image of Minna in 1986.

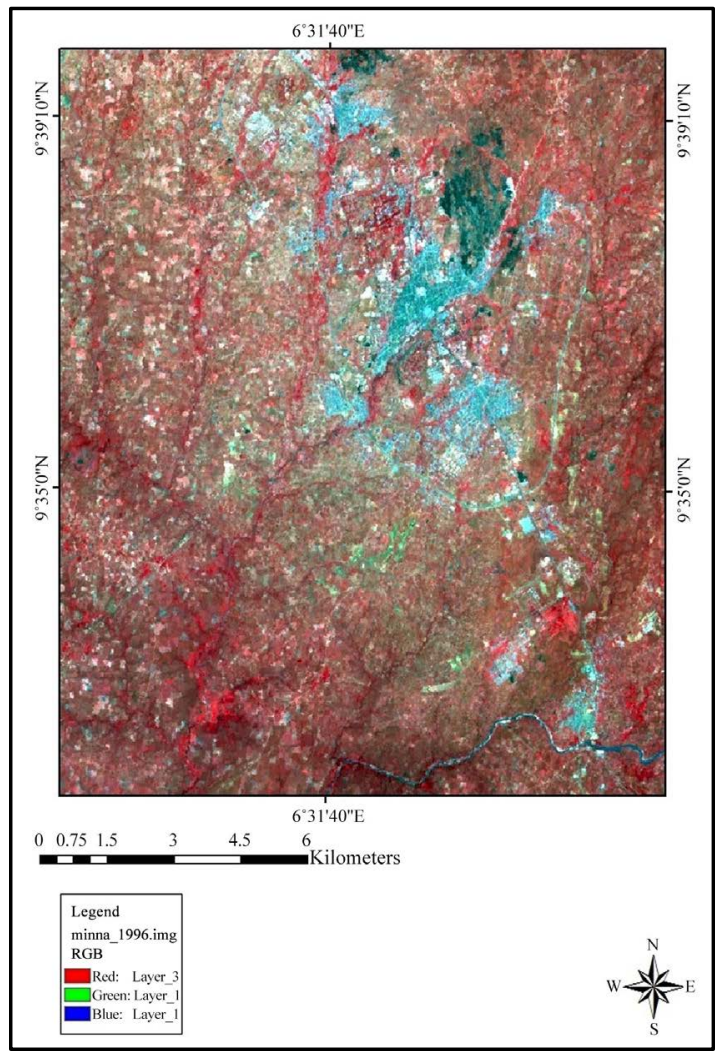

Figure 8. False colour composite image of Minna in 1996. 


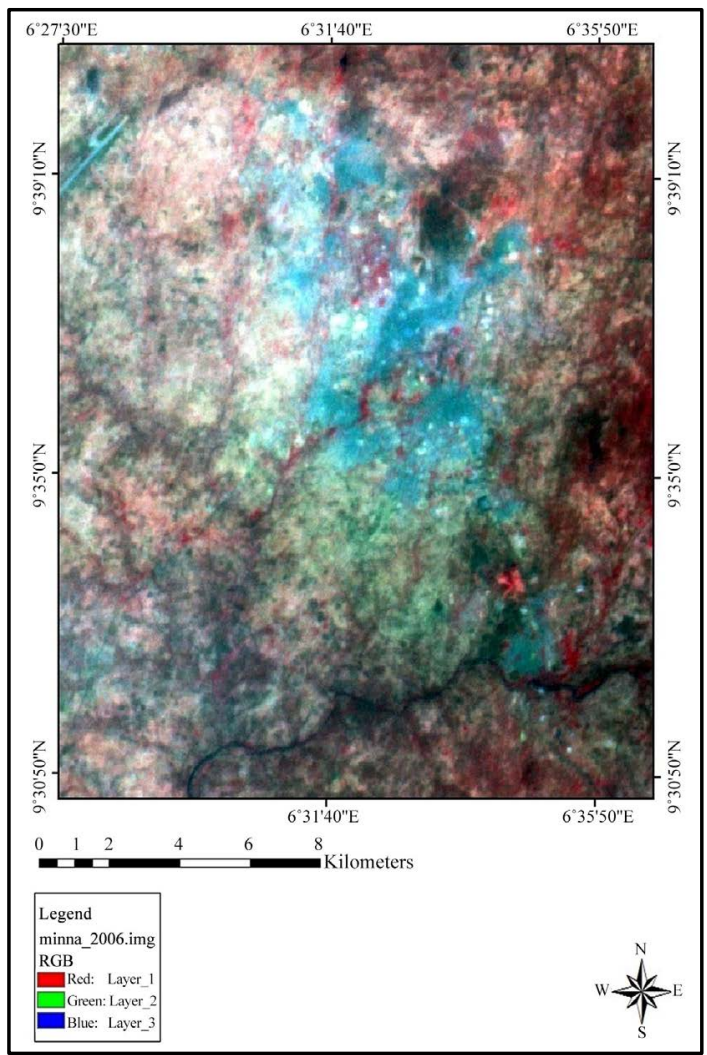

Figure 9. False colour composite image of Minna in 2006.

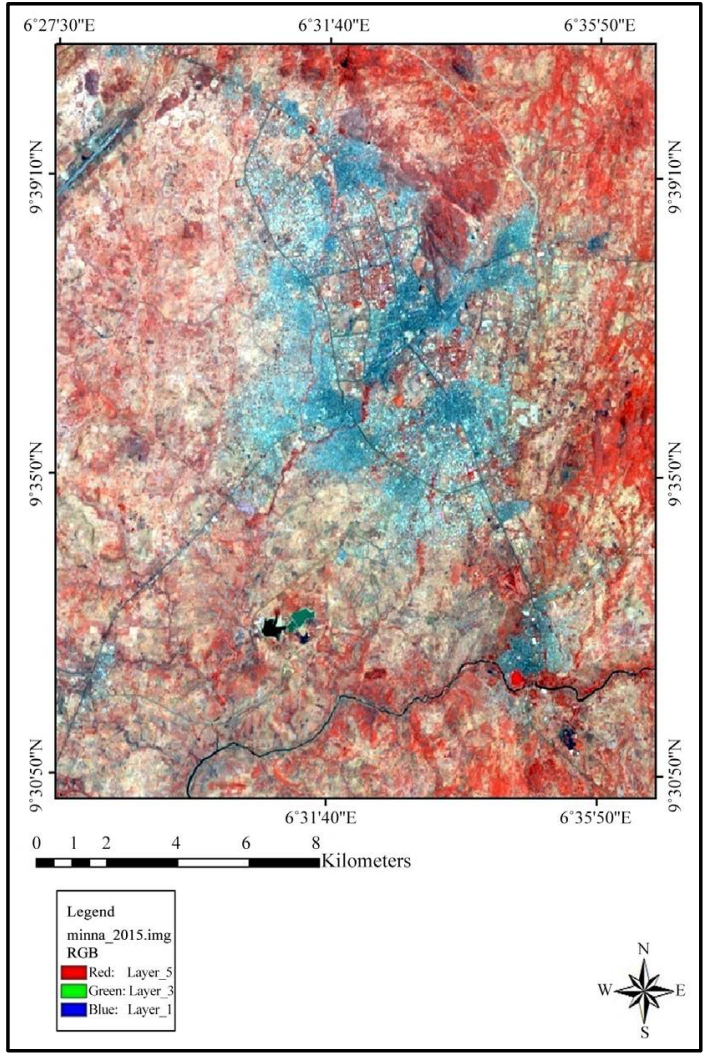

Figure 10. False colour composite image of Minna in 2015. 


\section{Results Discussion}

\subsection{Areal Extent of Minna: 1972 and 1979}

The availability of the topographical map of Minna (1972) and the township map of Minna (1979) which were converted from raster map to vector map using ERDAS IMAGINE 9.2 software, in the absence of digital satellite imageries for that periods afforded the opportunity to document the kind of changes in areal extent before and after Minna became the state capital.

According to Table 2, in 1972, Minna has a total land area of 368.31 hectares which represents less than $1 \%$ of the total land area selected as a subset of the town. The built-up area of Minna in 1972 (Figure 11) was densely clustered around the railway station. The satellite settlements that existed at that time are Kwangila, Makera, Limawa, Nasarawa, Tudunwada and the old GRA on the hilltop. The spatial arrangement of Minna in 1972 exhibits the characteristics of the concentric zone model by [16]. The railway station and the central market at Mobil areas constitute the Central Business District (CBD), while the residential area surrounding the CBD extended towards the fringe of the town.

In 1979, the built-up area of Minna (Figure 12) increased from 368.3 hectares in 1972 to 893.7 hectares in 1979 (Table 2). The doubling of the areal extent of Minna within seven years can be attributed to the change in the status of the town in 1976. In spite of this expansion, Minna remains a blend of traditional relics and modern architecture. Minna in 1979 exhibited "an axial growth" pattern, with its growth and development spreading out from the centre along the existing major transportation routes following the sectoral theory propounded by [17].

\subsection{Land Use Classification: 1986-2015}

The 1972 and 1979 data source did not permit any LU/LC classification beyond the observed areal extent of Minna. Meanwhile, the availability of satellite imageries for subsequent year afforded the opportunity of a four-digit classification used in this study. Thus, the land use/land cover classification of Minna employed the satellite imageries of 1986, 1996, 2006 and 2015. The imageries of different bands selected were combined using the process of image stacking in ERDAS IMAGINE 9.2 software, while the sub-setting of the area of study was done using the same software. The subset image was exported into ERDAS IMAGINE 9.2 software to develop the false colour composites (Figures 7-10).

Table 2. Areal extent of Minna in 1972 and 1979.

\begin{tabular}{ccc}
\hline Year & Area $(\mathrm{Ha})$ & \% of Area \\
\hline 1972 & 368.31 & 0.5 \\
1979 & 893.74 & 1.22 \\
Total & $73,351.50$ & -
\end{tabular}

Source: Authors' 2016. 


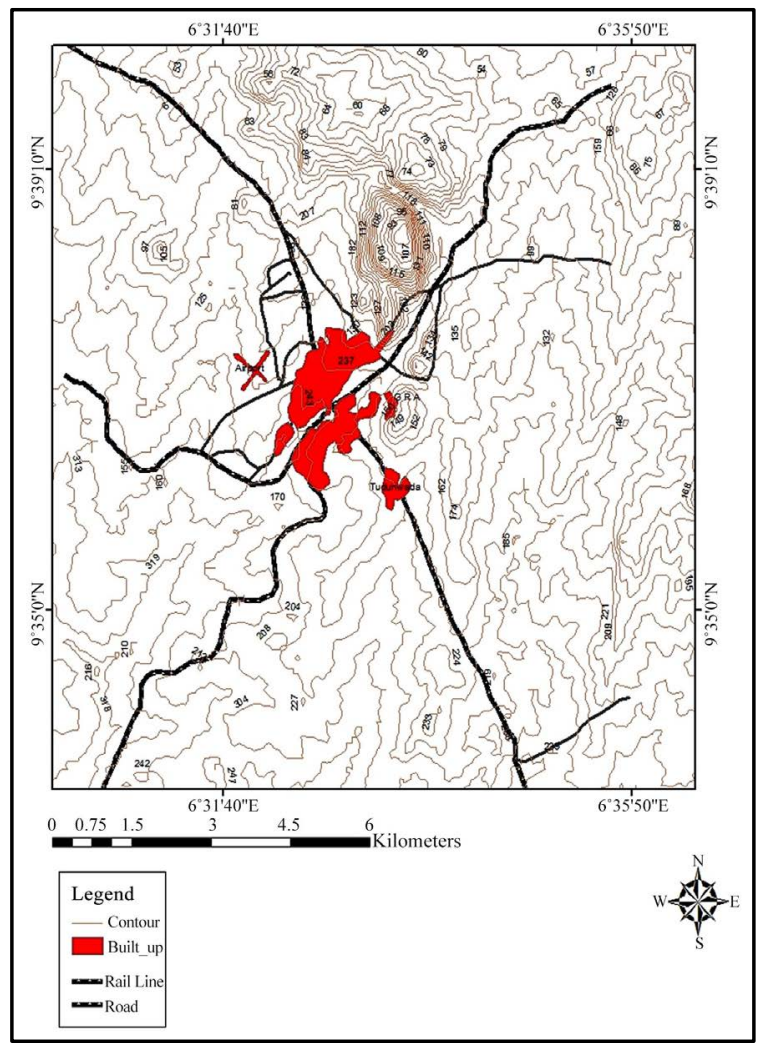

Figure 11. 1972 Topographical map of Minna.

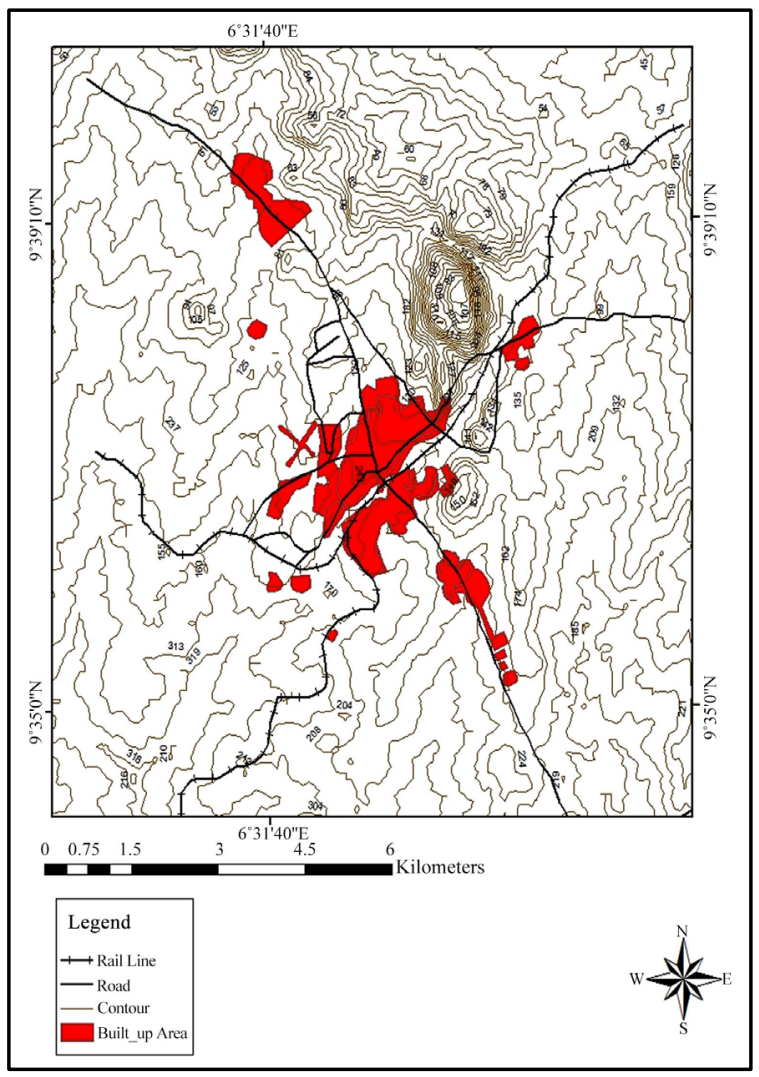

Figure 12. 1979 Township map of Minna. 
The supervised classification procedure was adopted because this permits the specification of parameters based on prior knowledge of the study area. The conventional supervised Maximum Likelihood Classification Algorithm was used to extract information from the satellite data and image analysis was carried out to detect the change in the land use/land cover (LU/LC) of Minna between 1986 and 2015. The total area for the land use/land cover classification is shown in Table 3; the graphical illustrations of the classified satellite imageries of Minna between 1986 and 2015 are shown in Figures 13-16.

Table 3. Land use/land cover classification of Minna: 1986-2015.

\begin{tabular}{|c|c|c|c|c|c|c|c|c|}
\hline \multirow{2}{*}{ Land use } & \multicolumn{7}{|c|}{ Area of Land in Hectares (Include 000) } & \multirow[b]{2}{*}{$\begin{array}{c}\% \\
\text { Coverage }\end{array}$} \\
\hline & 1986 & $\begin{array}{c}\% \\
\text { Coverage }\end{array}$ & 1996 & $\begin{array}{c}\% \\
\text { Coverage }\end{array}$ & 2006 & $\begin{array}{c}\% \\
\text { Coverage }\end{array}$ & 2015 & \\
\hline $\begin{array}{c}\text { Built-up } \\
\text { Area }\end{array}$ & 4368.7 & 5.96 & 4706.5 & 6.42 & 5904.5 & 8.05 & $11,913.2$ & 16.24 \\
\hline $\begin{array}{l}\text { Disturbed } \\
\text { Vegetation }\end{array}$ & $65,616.8$ & 89.46 & $55,816.8$ & 76.10 & $61,454.8$ & 83.78 & $53,535.3$ & 72.98 \\
\hline $\begin{array}{l}\text { Undisturbed } \\
\text { Vegetation }\end{array}$ & 3144.7 & 4.29 & $12,512.0$ & 17.06 & 5287.9 & 7.21 & 7568.6 & 10.32 \\
\hline Water Body & 221.3 & 0.30 & 316.2 & 0.43 & 704.4 & 0.96 & 334.4 & 0.46 \\
\hline Total & $73,351.5$ & 100 & $73,351.5$ & 100 & $73,351.5$ & 100 & $73,351.5$ & 100 \\
\hline
\end{tabular}

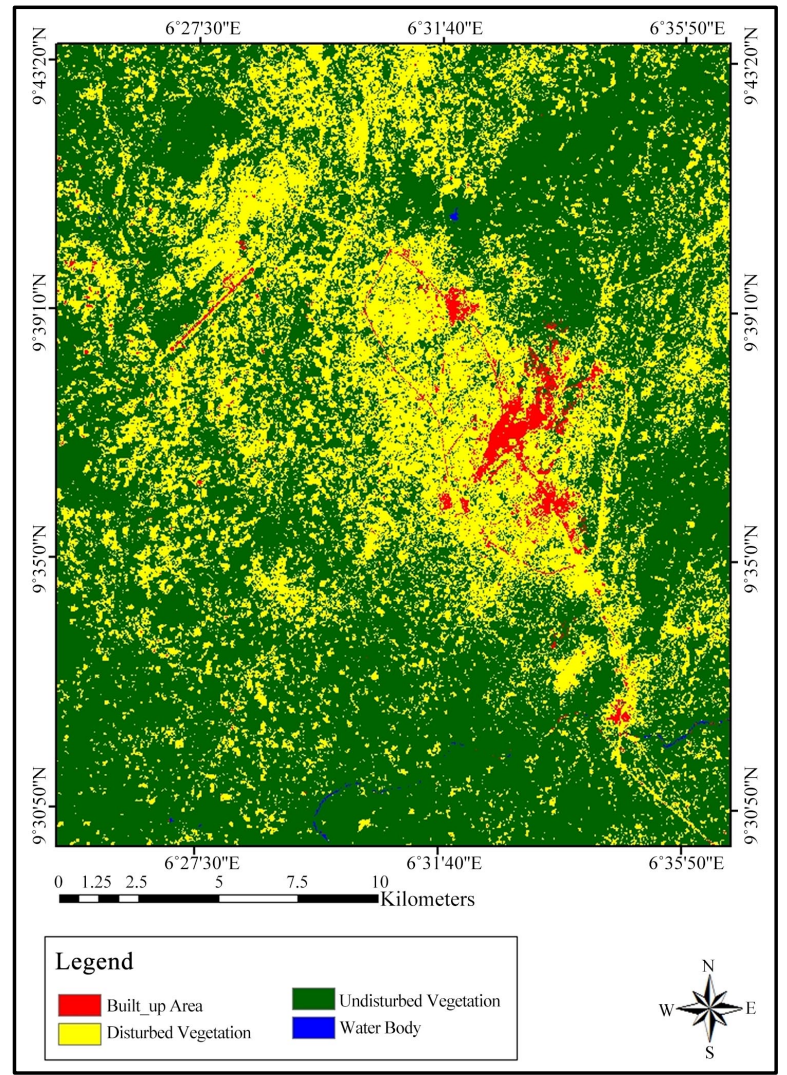

Figure 13. The classified image of Minna in 1986. 


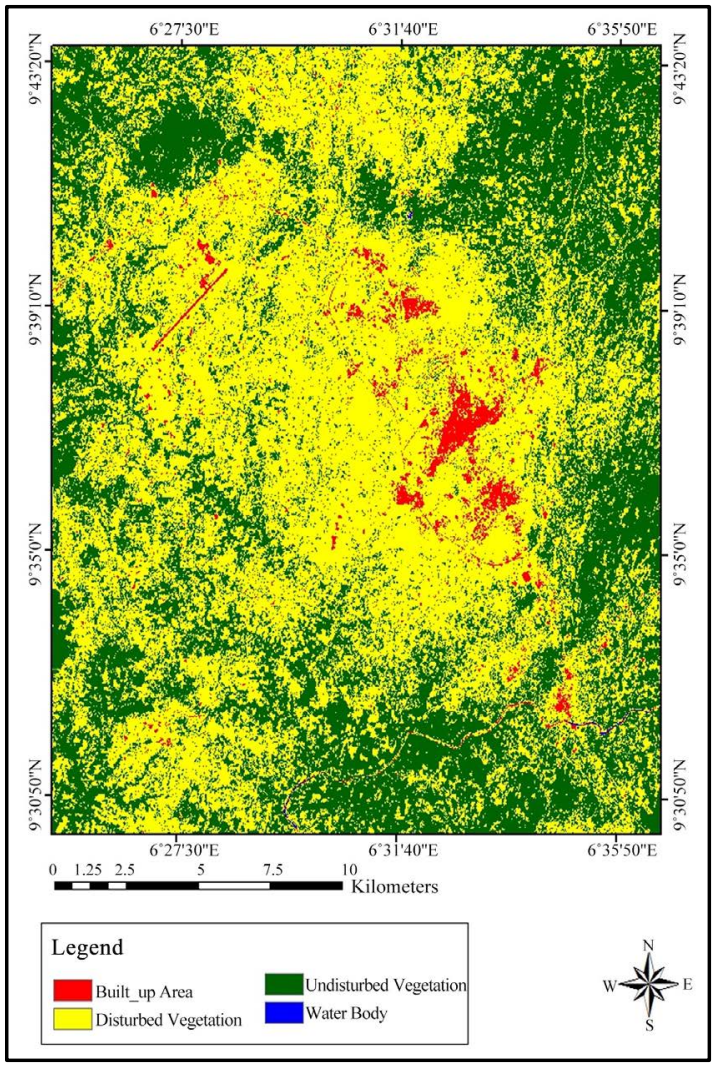

Figure 14. The classified image of Minna in 1996.

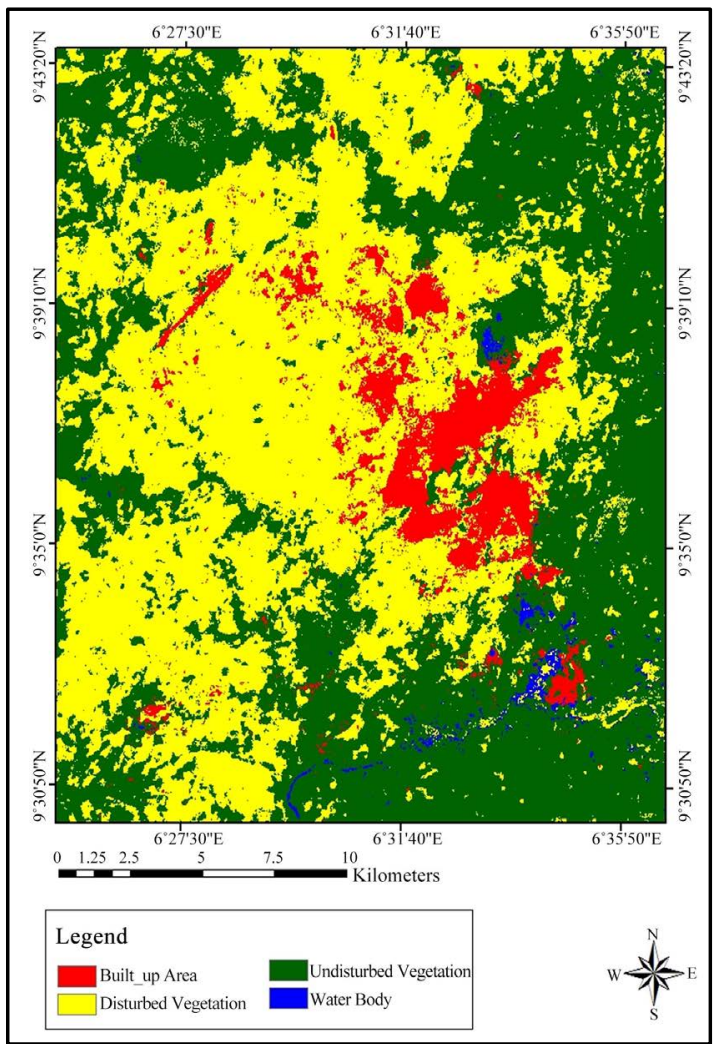

Figure 15. The classified image of Minna in 2006. 


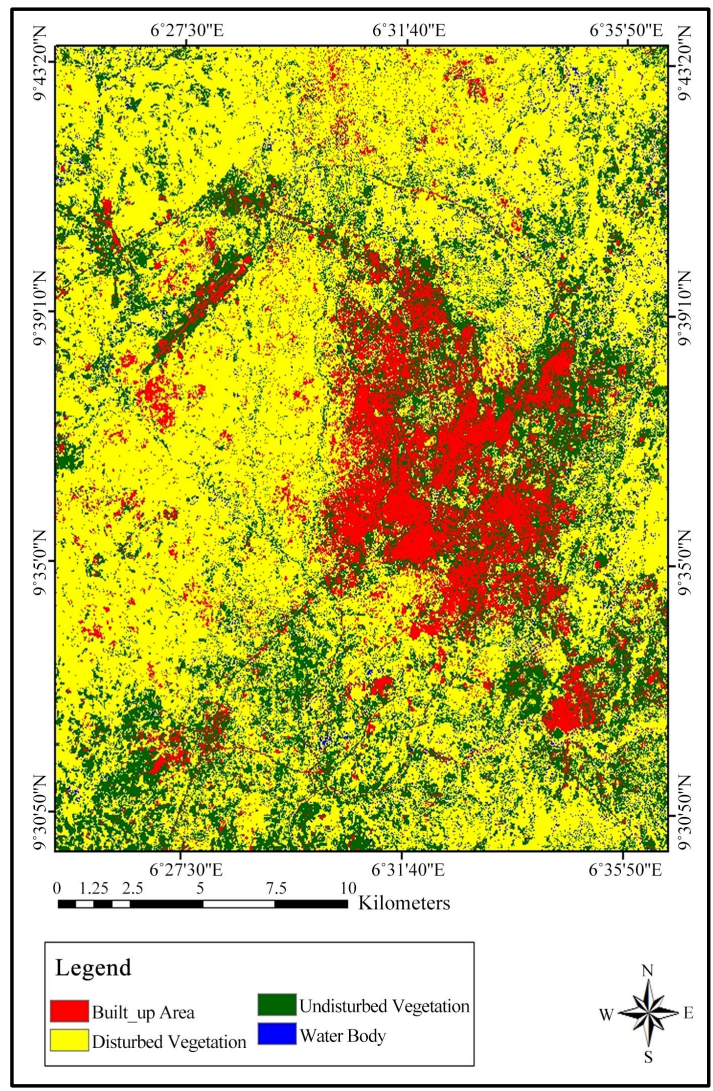

Figure 16. The classified image of Minna in 2015.

\section{Trend of the Peri-urban Built-up Area}

Table 4 shows the changes that occurred in the built-up area of Minna within the periods covered by the study. Expectedly, there has been a tremendous increase in the land developed in the town between 1972 and 2015. From a mere 368.3 hectares in 1972, Minna has increased to 11,913.2 hectares by 2015. A sharp increase in the areal extent of the town occurred between 1979 and 1986; from 893.7 hectares to 4368.7 hectares, respectively.

Figure 17 reveals the details of the magnitude of changes in the built-up area of Minna within the periods covered by the study. Between 1972 and 1979, the spatial area of Minna increased by 143\%, but remarkably between 1979 and 1986 when the increase was $388.8 \%$. This rapid change can be attributed to the rapid population increase, as a result of the new status of the town. The town drastically grew between 2006 and 2015. Indeed there was an increase of 102\% in less than a decade.

\section{Minna Peri-urban Development: 1972-2015}

The built-up area in the satellite imageries was digitized to conform to the raster maps of Minna in 1972 and 1979. These were used to reveal the changes that occurred in the peri-urban areas at different period intervals. These new maps largely provided the basis for comparing and determining the extent of the temporal changes in the peri-urban neighbourhoods of Minna.

In 1972 (Figure 18), Minna was a town predominately around the railway sta- 
tion. The built-up area was limited only to the densely nucleated settlement around the railway station, while the residential neighbourhoods surrounding it are Limawa, Makera, Nasarawa, Tudunwada and Old GRA. The neighbourhoods that were referred to as the peri-urban areas are Limawa, Makera, Angwa-Daji, Dutsen-Kura Hausa, New GRA, Tunga, F-Layout and the airport area.

Table 4. The built-up area of Minna: 1972-2015.

\begin{tabular}{ccccc}
\hline Year & Land Area $(\mathrm{Ha})$ & Area Changes $(\mathrm{Ha})$ & \% Increase & Remark \\
1972 & 368.31 & - & - & - \\
1979 & 893.74 & +525.43 & 142.66 & Increase \\
1986 & 4368.70 & +3474.96 & 388.81 & Increase \\
1996 & 4706.50 & +337.8 & 7.73 & Increase \\
2006 & 5904.50 & +1198.00 & 25.45 & Increase \\
2015 & $11,913.20$ & +6008.70 & 101.76 & Increase \\
$1972-2015$ & - & $+11,444.89$ & 2443.87 & Increase \\
\hline
\end{tabular}

Note: The sign + indicates the gain in the areal extent.

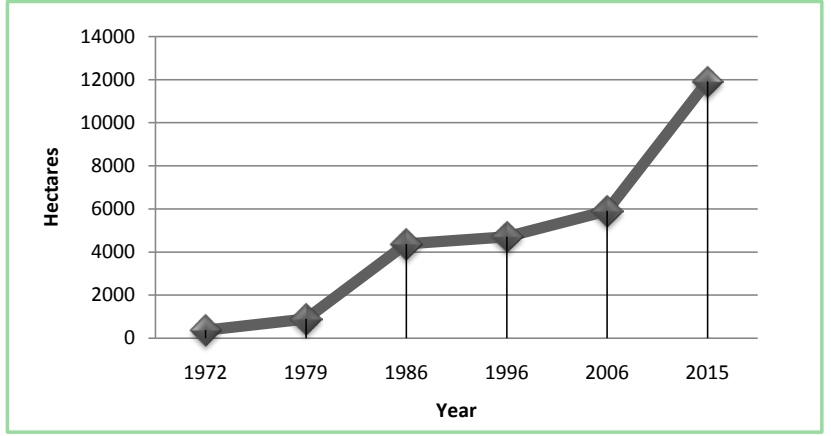

Figure 17. Trend in peri-urban built-area of Minna.

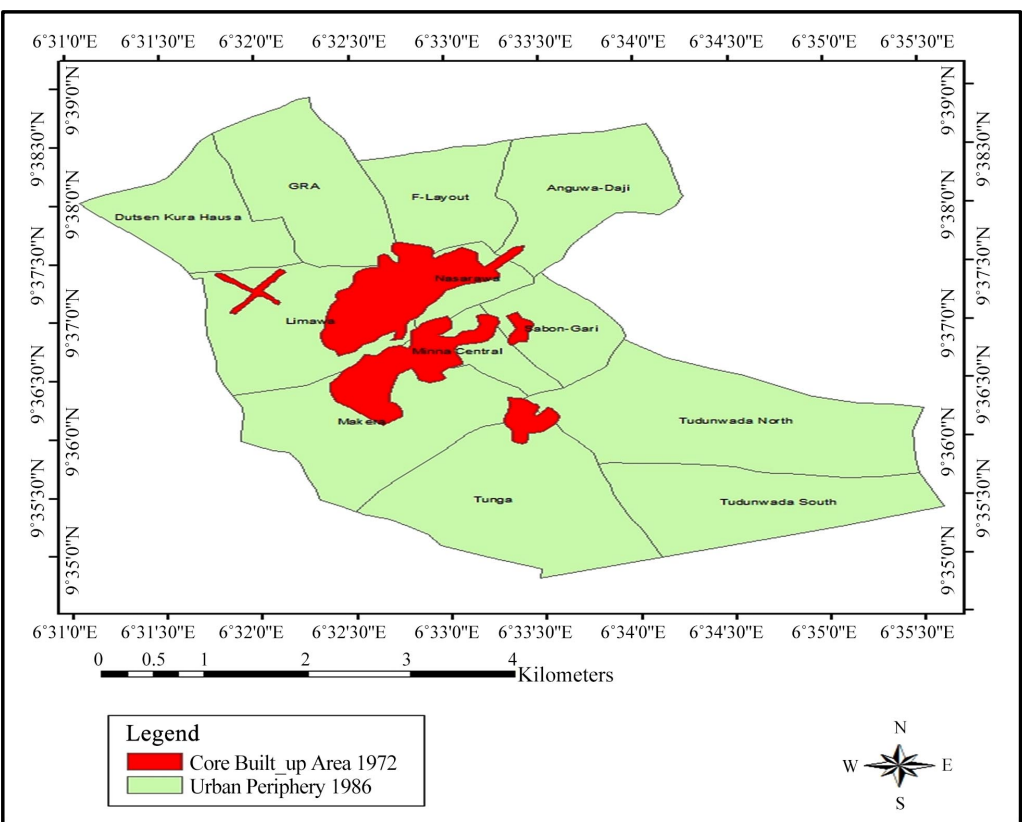

Figure 18. The 1972 peri-urban development. 
Figure 19 indicates four major settlements that were located within the peri-urban area of Minna in 1979. These settlements are Bosso to the north, Tudunwada to the south, Maitumbi to east and Kpakungun to the west. These neighbourhoods became the settlements that anchor further expansion of the peri-urban area of Minna. This supports role played by declaration of Minna as the administrative capital of Niger State, in 1976. After Minna became the State Capital, the non-residential land increased, the low-density and medium density housing also increased rapidly. The overall growth of Minna between 1972 and 1979 was estimated at the rate of $20.4 \%$ per annum.

Figure 20 shows the peri-urban areas of Minna in 1986. Between 1979 and 1986, the satellite settlements that were far away from the core area of Minna, expanded more toward the core area, taking the advantages of the newly constructed roads that linked the core area and the low cost housing estates. Developments in the peri-urban area of Minna began to take shape, though, rather scanty and few. These peri-urban neighbourhoods with various degrees of development are Bosso town, Tudunwada north and south, Tayi-Village, Maitumbi, Kpakungun, Dutsen Kura Gwari, Sango, Chanchaga, Tundun-Fulani, Jikpan and Bosso Estate.

The development of the peri-urban area of Minna increased, but rather slowly (Figure 21). Between 1986 and 1996, there were more of dispersed developments outside the designated core area of Minna and this displayed the linear strip pattern along the major highways and access roads. Neighbourhoods such as Tudunwada, Tunga, F-layout and GRA, developed toward the core area of Minna, while neighbourhoods like Bosso town, Tayi village, Kpakungun and Chanchaga developed in different directions.

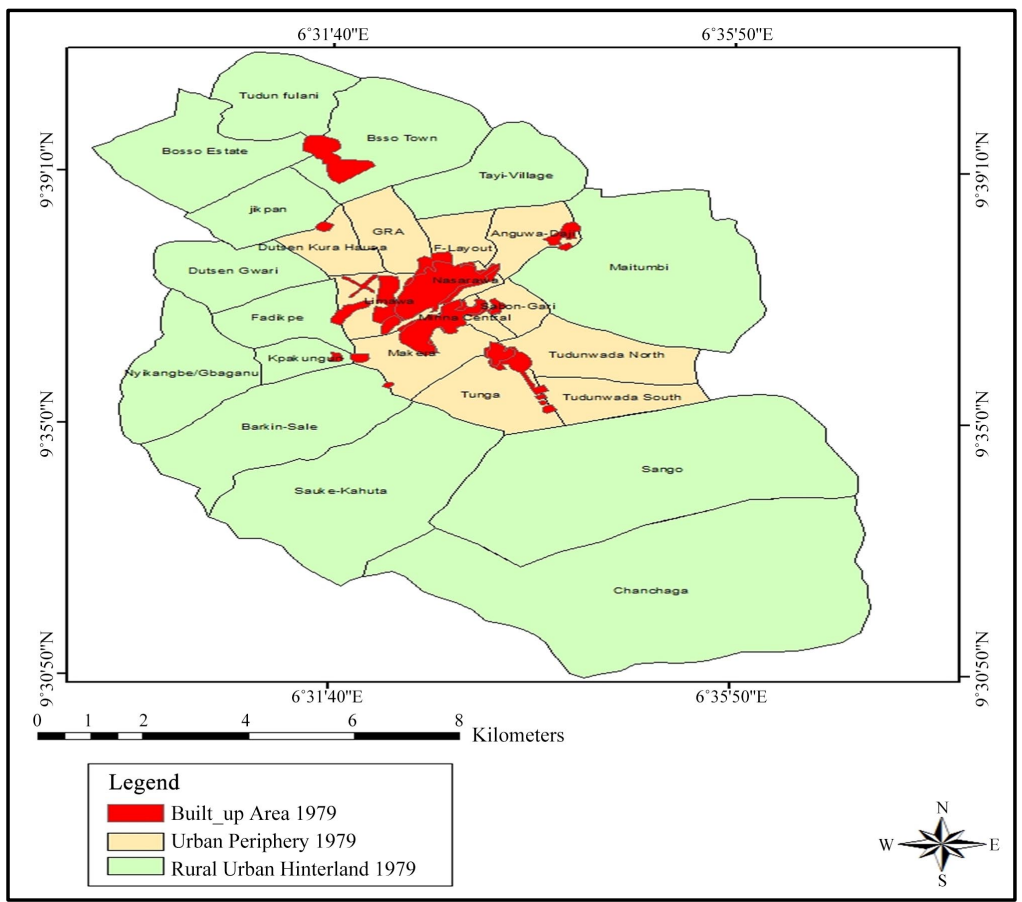

Figure 19. 1979 Peri-urban development. 


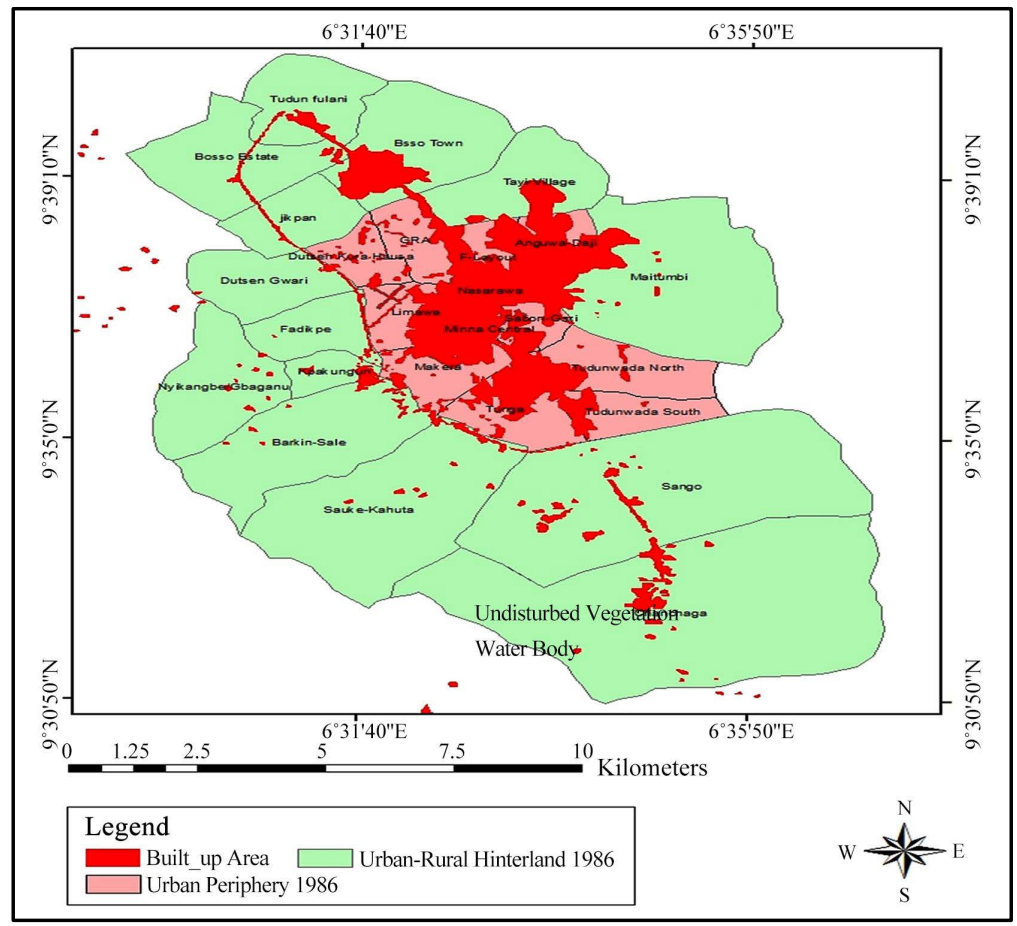

Figure 20. 1986 Peri-urban development.

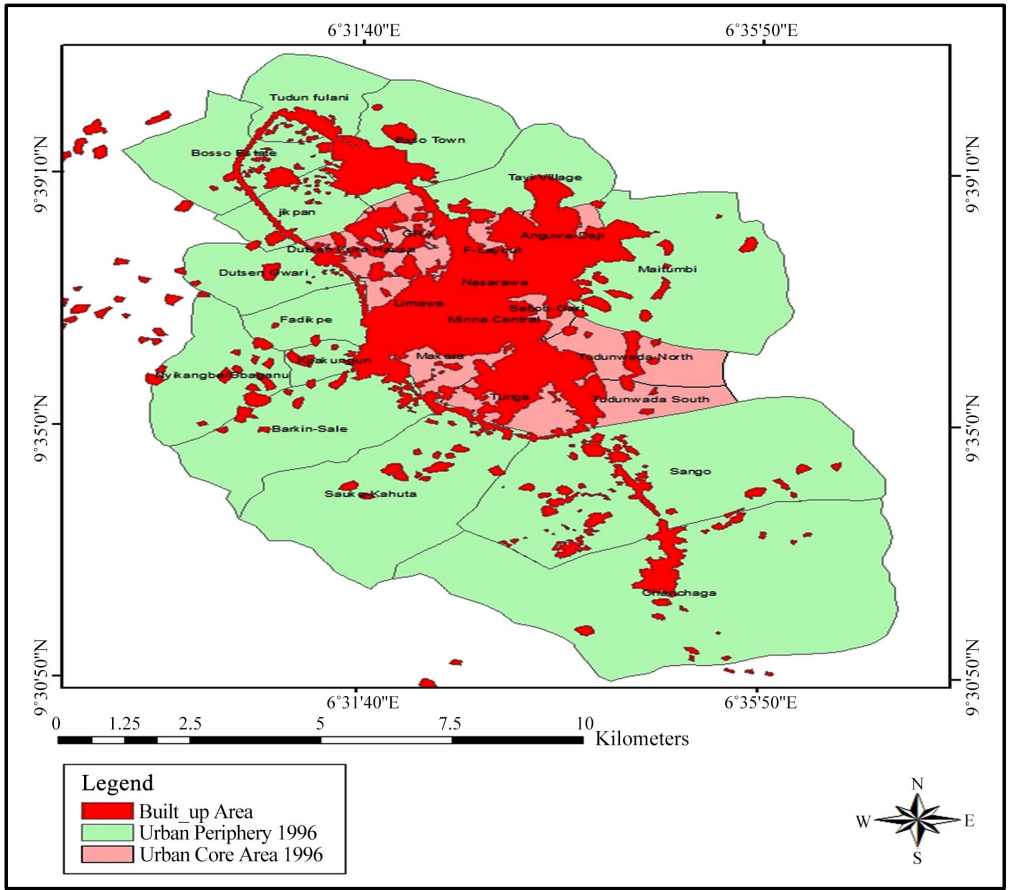

Figure 21. 1996 Peri-urban development.

The peri-urban development of Minna in 2006 is shown in Figure 22. During this period, Minna could be seen as a spatially clustered city. Actually, the development of the peri-urban area of Minna in 2006 could be described as dramatic, because the major parts of the peri-urban and the core area became fused. The neighbourhoods affected are those of Tudun-Fulani, Bosso town, Tayi-village, 
Kpakungun, Dutsen Kura-Gwari, Jikpan and Bosso Estate.

The peri-urban area of Minna in 2015 has grown tremendously (Figure 23) to the extent that [18] described Minna as a highly cosmopolitan community. This growth of peri-urban neighbourhoods of Minna is unlike the growth of a typical northern Nigerian city. Accessibility to land for different purposes was identified as one of the major reasons for this pattern of expansion.

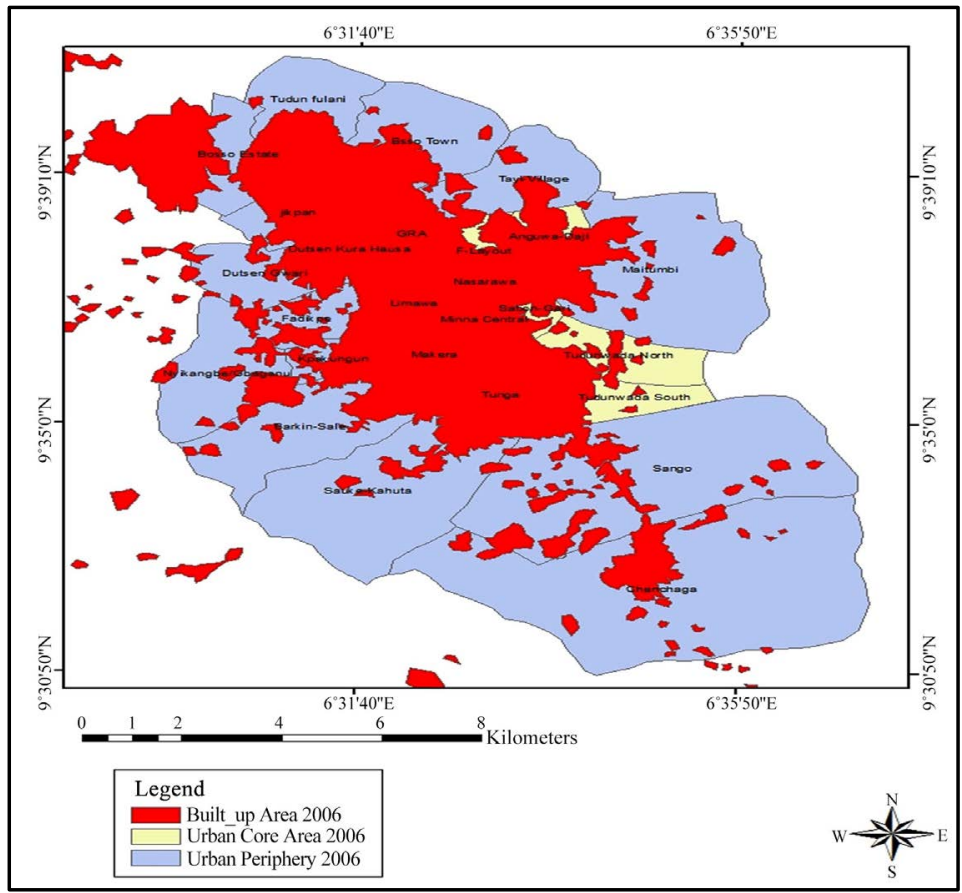

Figure 22. 2006 Peri-urban development.

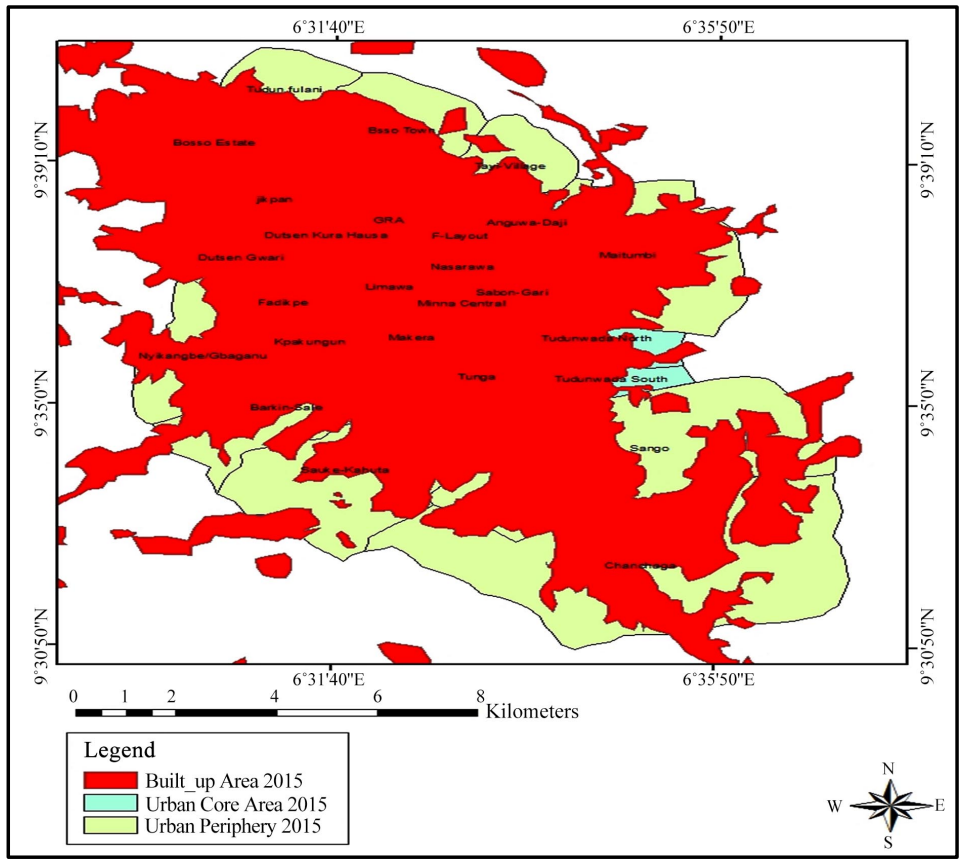

Figure 23. 2015 Peri-urban development. 
The built-up areas of Minna (Figure 24), Minna were thirty-two times its size in 1972; thirteen times its size in 1979; thrice its size in 1986 and 1996, respectively; and twice of its size in 2006. [19] best explained the situation of Minna in 2015 because of the decentralization of urban functions outside the core areas of the city. According to Figure 24, Minna expands more toward the westward direction, where the Federal University of Technology, permanent site and the National Examination Council (NECO) headquarters are located. Besides, the expansion of Minna toward the west is due to the western bypass with the two flyovers constructed over the rail-lines and over the River Suka to connect Minna-Bida road in the western area of Minna. The town also expands toward the eastward direction along Maitumbi toward Gwada road (Figure 25). The town spread toward the southeast in Chanchaga and in southward along Minna-Suleja road.

\section{Conclusion and Recommendations}

This study documented the spatial development of peri-urban area of the Minna between 1972 and 2015 using geo-spatial data. Expectedly, there was over 2000\% increase in the built-up area of Minna between 1972 and 2015. This implies that Minna by 2015 had grown about thirty-two times its size in 1972; thirteen its size in 1979; thrice its size in 1986 and 1996, respectively; and twice of its size in 2006. Consequently, with the development of peri-urban areas of Minna the political, economic, spatial and environmental landscape of the town has been affected; with an increase in proliferation of informal and unplanned peri-urban neighbourhoods. Now that achieving a sustainable strategy for peri-urban planning has become imperative, planning and development of such areas should

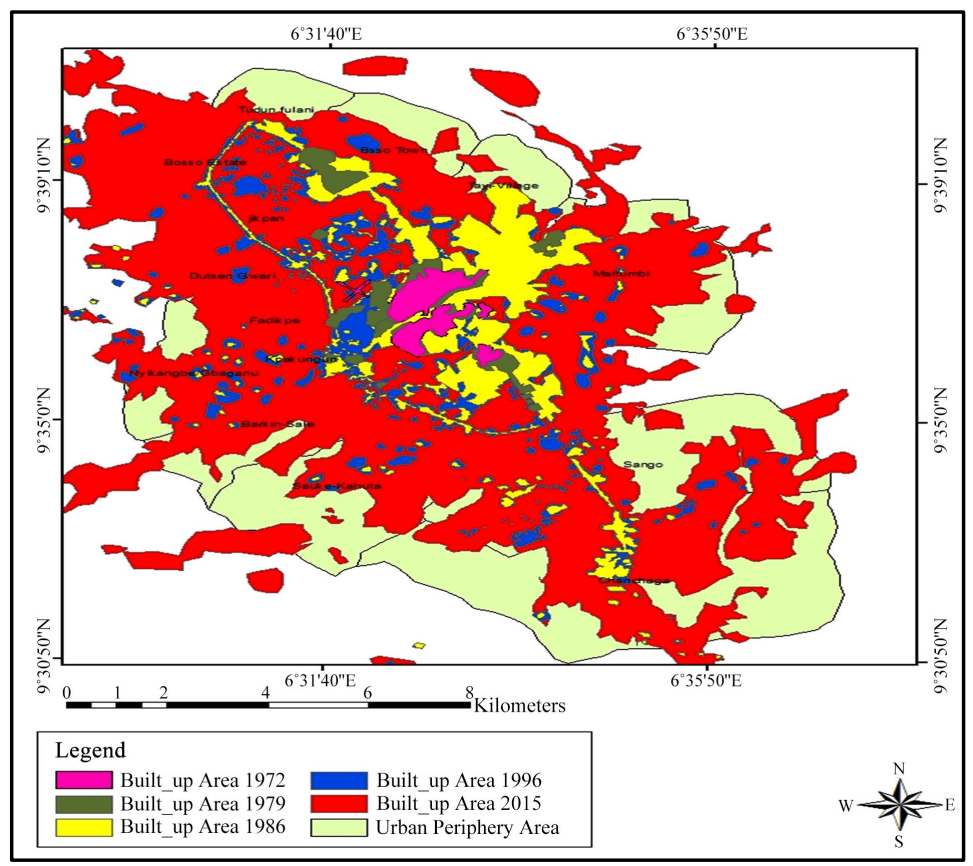

Figure 24. Map overlay of Minna 1972-2015. 


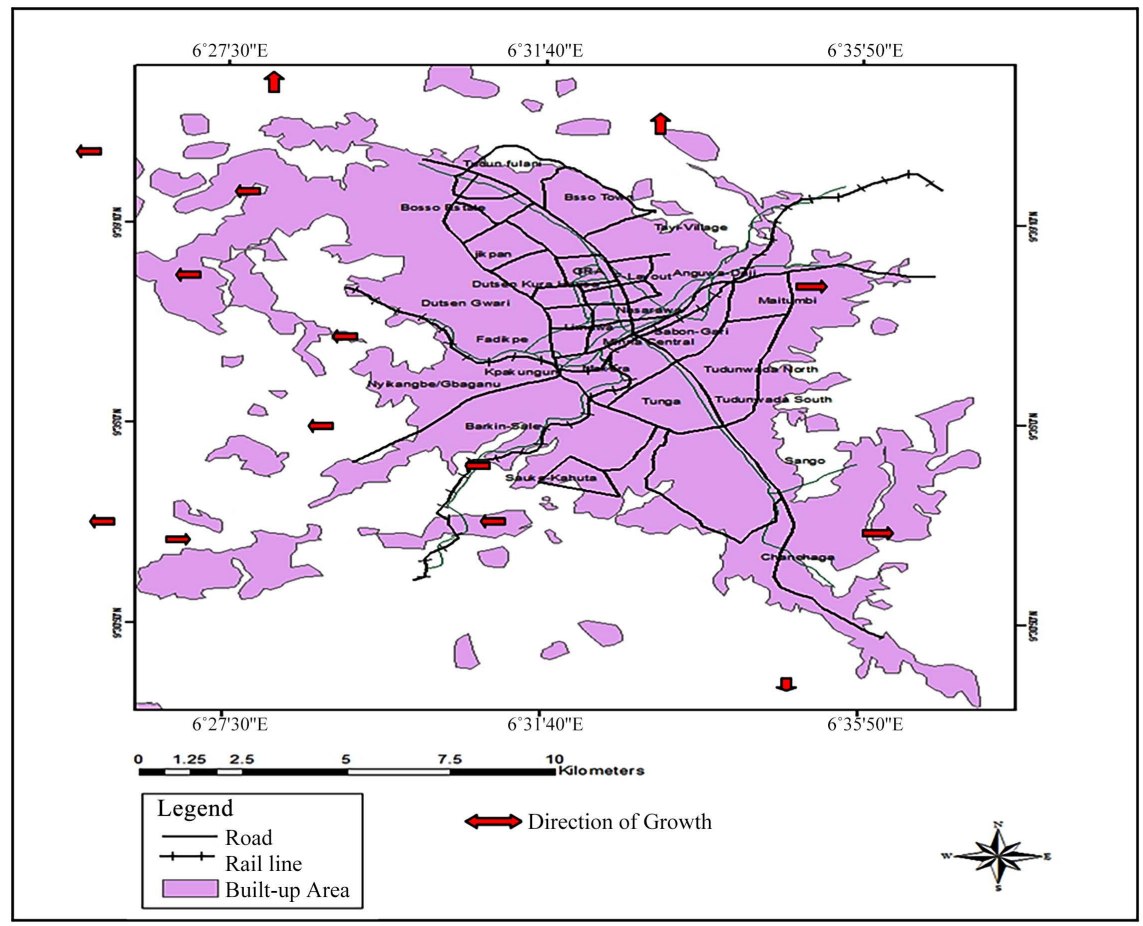

Figure 25. Direction of peri-urban growth in Minna.

not be left to chance or the interplay of economic variables. But, the development of the peri-urban areas of Minna should be guided by strategies that will ensure orderly growth and the provision of necessary infrastructure and services in the peri-urban areas.

\section{Conflicts of Interest}

The authors declare no conflicts of interest regarding the publication of this paper.

\section{References}

[1] UN-Habitat (2013) The State of the World's Cities 2012/2013: Prosperity of Cities. Routledge, London. https://doi.org/10.4324/9780203756171

[2] Knox, P.L. and McCarthy, L. (2005) Urbanization: An Introduction to Urban Geography. 2nd Edition, Pearson Education Inc., London.

[3] Wan-Ibrisam, F. (1996) Urban Growth Determinant for the State of Kelantan: Opinion of the State Policy Makers. Bulletin Ukur, Jld.7, No.3, Ms. 176-189.

[4] Simon, D., McGregor, D. and Nsaih-Gyabaah, K. (2004) The Changing Urban-Rural Interface of African Cities: Definitional Issues and an Application to Kumasi, Ghana. Journal of Environment and Urbanization, 16, 235-248. https://doi.org/10.1177/095624780401600214

[5] Pacione, M. (2001) Models of Urban Land Use Structure in Cities of the Developed World. Geography, 86, 97-119.

[6] Ogunsanya, A.A. (2002) Maker and Breaker of Cities. Being the 59th Inaugural Lecture of University of Ilorin, Ilorin.

[7] Dutta, V. (2012) War on the Dream: How Land uses Dynamics and Peri-Urban 
Growth Characteristics of a Sprawling City Devour the Master Plan and Urban Sustainability a Fuzzy-Criteria Decision Making Approach. 13th Annual Global Development Conference on Urbanization and Development. Delving Deeper into the Nexus, Global Development Network, 16-18 June 2012, 3-5.

[8] Idowu, O.O. (2017) Spatio-Temporal Analysis of Peri-urban Development in Minna, Niger State. Ph.D. Thesis, University of Ilorin, Ilorin Kwara State.

[9] Johnson, M.P. (2001) Environment Impacts of Urban Sprawl: A Survey of the Literature and Proposed Research Agenda. Environment and Planning A: Economy and Space, 33, 717-735. https://doi.org/10.1068/a3327

[10] Lamond, J., Awuah, B.K., Lewis, E., Bloch, R. and Falade B.J. (2015) Urban Land, Planning and Governance Systems in Nigeria. Urbanisation Research Nigeria (URN) Research Report. ICF International, London. https://assets.publishing.service.gov.uk//61250-URN

[11] Cillier, D.P. (2010) The Development and Use of Land Use Suitability Model in Spatial Planning in South Africa. M.sc Thesis, Potchefstroom Campus of the North West University, Potchefstroom.

[12] Noor, N.M. and Rosini, N.A. (2013) Determination of Spatial Factors in Measuring Urban Sprawl in Kuantan Using Remote Sensing and GIS. ASEAN Conference on Environment-Behavior, Hanoi Architectural University, Hanoi, 19-22 March 2013. Studies Social and Behavioral Sciences. https://www.sciencedirect.com/

[13] Sanusi, Y.A. (2006) Pattern of Urban Land Development Control in Nigeria: A Case Study of Minna, Niger State. Journal of the Nigerian Institute of Town Planners, 19, 125-145.

[14] Niger State Government (2007) Niger State Produce, Power and Prosperity: Development Action Plan (DAP) for Niger State. Niger State Government, Nigeria.

[15] Niger State Government (2009) Vision 3:20:20. Niger State Nigeria, Nigeria.

[16] Burgess, E. (1925) The Growth of the City: An Introduction to a Research Project. In: Park, R.E., Burgers, E.W. and McKenzie, R.D., Eds., The City, University of Chicago Press, Chicago.

[17] Hoyt, H. (1939) The Structure and Growth of Residential Neighborhoods in American Cities. Federal Housing Administration, Washington DC.

[18] Orintunsin, J. (2014) Minna: A Blend of Colonial Relics and Modern Architecture. In Saturday Magazine the Nation Newspaper. http://thenationonline.net/minna-a-blend-of-colonial-relics....thenationonline.net

[19] Vance, J.E. (1964) Geography and Urban Evolution in the San Francisco Bay Area. Berkerley: Institute of Government, University of California. 